\title{
NOVOS TALENTOS
}

Passaram-se 34 anos desde a publicação do primeiro número da Acta Amazonica em março de 1971. Aquele primeiro número tinha apenas 94 páginas com 12 artigos, desde então crescemos, este número tem 110 páginas e 14 artigos, e publicamos a média de 168 páginas por número nas últimas quatro edições (Figura $1^{*}$ ). Tem sido um trabalho apaixonante produzir esta revista, pois me sinto privilegiado pela oportunidade de dirigir e projetar a AA da situação que se encontrava em 2002, para a de hoje. De certo modo, isto me permite saldar parcialmente o débito de gratidão que tenho com Marcus Barros, que me deu a oportunidade de aprender uma segunda ocupação, aqui na editoração, além da minha profissão de biólogo e pesquisador. Tenho feito o melhor para que a revista seja abertamente receptiva aos novos pesquisadores, talentos emergentes da pesquisa científica e tecnológica na Amazônia.

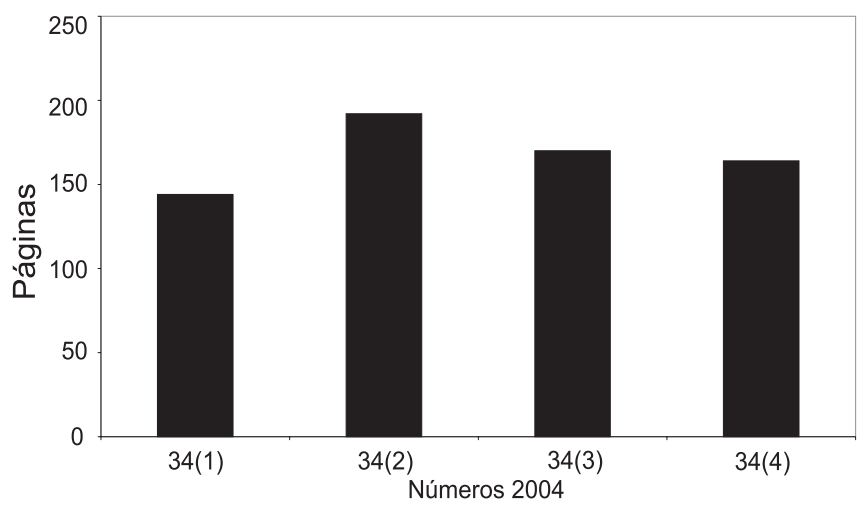

Figura 1 - Número de páginas publicadas por número na Acta Amazonica em 2004.

Publicar trabalhos de talentos locais tem sido a missão da revista desde seu lançamento, especialmente de estudantes e pesquisadores da própria instituição, estimulados a melhorar e publicar seus trabalhos ao longo dos anos. Mas, recentemente percebemos um aumento gradual na percentagem de autores de outras instituições publicando seus artigos, e o balanço geral entre autores que possuem algum vínculo com o INPA e autores de outras instituições, pende a favor da ampla comunidade de pesquisadores que tem da Amazônia como objeto de estudo, independente de instituição, estado ou país (Figura $2^{*}$ ).

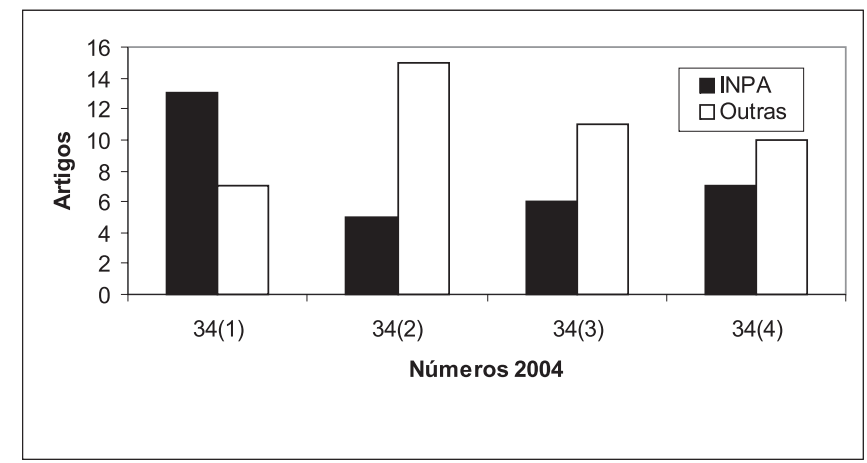

Figura 2 - Número de artigos publicados por autores do INPA e de outras instituições na Acta Amazonica em 2004. 
Esperamos publicar artigos das diferentes áreas do conhecimento, procurando um equilíbrio, evitando que uma ou duas predominem na revista (Figura 3*). Áreas tradicionais como a Botânica apresentaram um gradual aumento no número de artigos publicados, outras áreas tão tradicionais quanto, como Agronomia, Zoologia e Saúde sofreram redução. Recentemente surgiram mais artigos na área de Ecologia, Floresta e outras áreas como Arqueologia, Climatologia e Genética.

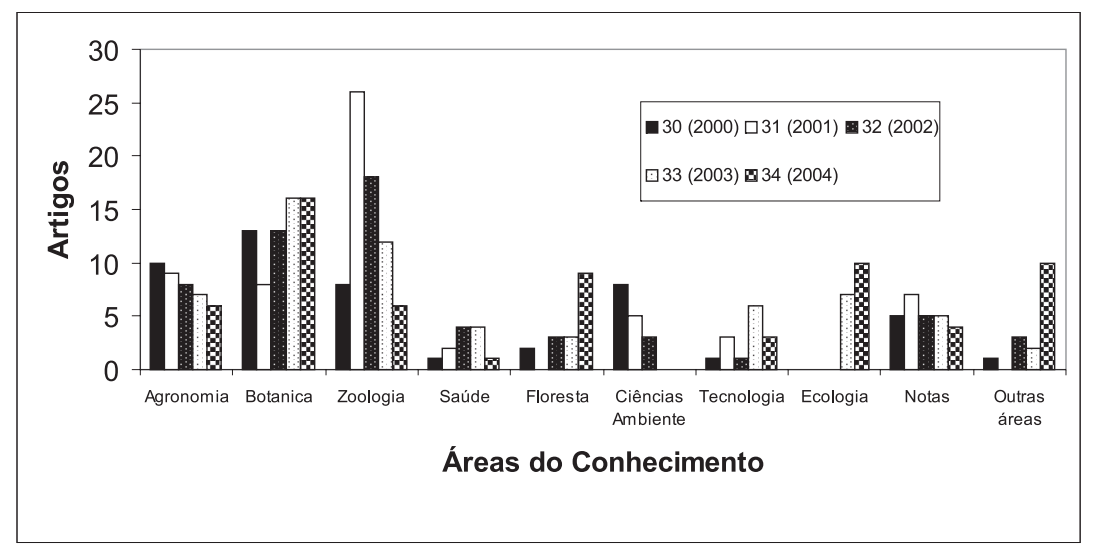

Figura 3 - Número de artigos publicados por área de conhecimento nos últimos 5 anos na Acta Amazonica.

Estas mudanças na revista revelam um crescente interesse pelo que publicamos e onde publicamos. Em março de 2005 comemoramos a marca dos mais de 30.000 acessos desde que começou a funcionar nosso site no SciELO em agosto de 2004 até hoje, além dos acessos normais pelo portal do INPA. Esta marca é compatível com o reconhecimento da revista como nível A em 6 dos 13 comitês de avaliação da CAPES, e a inclusão dos dois endereços eletrônicos no Portal de Periódicos CAPES. Nosso fator de impacto hoje já mensurável de apenas 0,0135 sinaliza o início modesto na web da única revista Amazônica com versões eletrônicas indexadas e com texto integral.

As versões eletrônicas são fruto do trabalho dedicado e quase anônimo de jovens estagiários, compilando os textos formatados, organizando o portal e enviando arquivos. Precisamos agora de pessoal para operar bancos de dados, contatar autores, subeditores e produzir as versões eletrônicas com uma rapidez jamais sonhada. Se alguém está interessado em ser bolsista da AA, ajudando bastante no processo editorial pode nos contatar. Precisa ter habilidade para trabalhar com Linux e ser competente no uso do programa Adobe PageMaker, é desejável formação na área de comunicação e grande interesse em lidar com o público crescente que nos procura a cada dia. Precisamos de novos talentos de todas as áreas que nos ajudem a fazer a principal revista científica da Amazônia cada vez mais atraente.

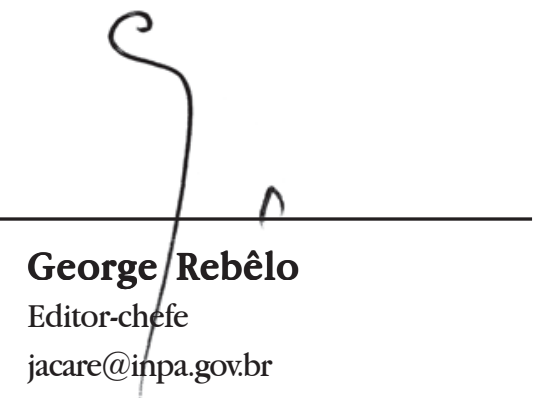

